\title{
Node-Negative Breast Cancer: Which Patients Should Be Treated?
}

\author{
Marcus Schmidt \\ Department of Obstetrics and Gynecology, Johannes Gutenberg University, Mainz, Germany
}

\section{Key Words}

Breast cancer - Node-negative · Risk category . Adjuvant! · uPA/PAI-1 · Gene expression profiling

\section{Summary}

Adjuvant systemic therapy has led to markedly improved outcome in early-stage breast cancer. However, the absolute gains from chemotherapy might be modest in node-negative patients. Adjuvant chemotherapy is the only option for triple-negative breast cancer patients and should be used with trastuzumab in HER2-positive patients. Considering the large group of patients with some degree of endocrine responsiveness, adding chemotherapy according to risk is an option. At present, we guide our therapeutic decisions using clinicopathologic risk classifications like the St. Gallen risk category or Adjuvant! online. A downside of these risk estimations is a low specificity and consequently the risk for overtreatment of a considerable number of patients. To spare patients unnecessary toxicities we need more reliable prognostic factors or tumor markers. From the plethora of tumor markers, only urokinase-type plasminogen activator (uPA)/plasminogen activator inhibitor 1 (PAI-1) and certain multiparameter gene expression assays are recommended by the American Society of Clinical Oncology. These tumor markers are presently investigated in clinical trials in node-negative breast cancer (NNBC-3, MINDACT, TAILORx). These studies will hopefully allow us to quantify the risk of progression in the individual patient and to tailor treatment accordingly. This should lead to a more personalized treatment recommendation.

\section{Schlüsselwörter}

Mammakarzinom · Nodal-negativ · Risikoeinteilung ·

Adjuvant! · uPA/PAI-1 - Genexpression

\section{Zusammenfassung}

Durch adjuvante medikamentöse Therapien konnte die Prognose des Mammakarzinoms deutlich verbessert werden, auch wenn der absolute Nutzen bei nodal-negativen Patientinnen oft nur mäßig ist. Adjuvante Chemotherapie ist die einzige medikamentöse Option bei Mammakarzinomen, die negativ für Hormonrezeptoren und HER2 sind, und sollte zusätzlich zu Trastuzumab bei HER2-positiven Mammakarzinomen eingesetzt werden. Bei hormonabhängigen Mammakarzinomen kann eine Chemotherapie risikoadaptiert eingesetzt werden. Derzeit werden zur Risikoabschätzung klinisch-pathologische Klassifikationen wie die St. Gallen Risikoeinteilung oder das computergestützte Berechnungsmodell Adjuvant! eingesetzt. Ein Nachteil dieser Risikoeinteilungen ist die geringe Spezifität und das damit einhergehende Risiko einer Übertherapie. Von den zahlreichen zusätzlich bislang untersuchten Prognosefaktoren wurden nur urokinase-type plasminogen activator (uPA)/plasminogen activator inhibitor 1 (PAI-1) sowie bestimmte multiparametrische Genexpressionsanalysen von der American Society of Clinical Oncology (ASCO) empfohlen. Diese Prognosefaktoren werden derzeit im Rahmen von multizentrischen klinischen Studien (NNBC-3, MINDACT, TAILORx) beim nodal-negativen Mammakarzinom untersucht und sollten in der Zukunft eine risikoadaptierte und individualisierte adjuvante Therapie des Mammakarzinoms ermöglichen.

\begin{tabular}{ll}
\hline KARGER & @ 2008 S. Karger GmbH, Freiburg \\
Fax +49 7614520714 & Accessible online at: \\
$\begin{array}{l}\text { E-mail Information@Karger.de } \\
\text { www.karger.com }\end{array}$ & www.karger.com/brc
\end{tabular}

Dr. Marcus Schmidt

Klinik und Poliklinik für Frauenheilkunde und Geburtshilfe

Klinikum der Johannes Gutenberg-Universität

Langenbeckstr. 1, 55131 Mainz, Germany

Tel. +49 6131 17-2683, Fax -5673

marcus.schmidt@frauen.klinik.uni-mainz.de 


\section{Introduction}

In the last decades, breast cancer mortality has been declining in Western countries. Much of this decline has been attributed to early detection and to the use of adjuvant systemic therapy [1].

Adjuvant systemic therapy has greatly improved survival in early breast cancer not only in node-positive but also in nodenegative disease [2]. The absolute magnitude of benefit, however, is higher in node-positive as compared to node-negative patients. This progress in adjuvant systemic therapy has led to consensus recommendations proposing adjuvant systemic therapy for virtually all breast cancer patients [3]. Yet, potential adverse effects of adjuvant therapy may affect the quality of life $[4,5]$.

Thus, the question '... which patients should be treated?' should be modified to its contrary. Nowadays, it seems more appropriate to ask which patients could be spared a potentially toxic adjuvant therapy.

As pointed out in the current St. Gallen recommendations, the treatment decisions should be based primarily on the degree of endocrine responsiveness and on HER2 (table 1). Endocrine treatment is advised in endocrine-responsive patients even with a low risk of disease recurrence. Chemotherapy is the only option in cases that are both endocrine receptor negative and HER2 negative (so-called triple-negative cases). The St. Gallen consensus panel stated that chemotherapy should be given with or preceding trastuzumab for patients with HER2-positive disease, and may be used for patients with endocrine-responsive disease in cases where the sufficiency of endocrine therapy alone is uncertain. In HER2-negative patients who are highly or incompletely endocrine responsive, chemotherapy should be considered according to the level of risk.

Indeed, in order to avoid over- as well as undertreatment, it is still advisable to select the appropriate treatment strategy on the basis of a careful risk assessment for each individual patient. Beyond any doubt, the single most important histopathologic factor for risk stratification in primary breast cancer is nodal status [6-8]. Due to earlier detection there are considerably more node-negative than node-positive patients diagnosed. More than two thirds of patients with node-negative breast cancer are alive at 10 years even without adjuvant systemic therapies [6, 7]. However, long-term follow-up of patients randomized to tamoxifen in the NSABP B-14 trial showed that the prognosis of estrogen receptor (ER)-positive patients can be remarkably improved by the use of this endocrine therapy [9]. Building on these findings, the NSABP B20 trial investigated the addition of chemotherapy with cyclophosphamide, methotrexate, fluorouracil (CMF) to tamoxifen in node-negative breast cancer patients and found further improvement in outcome [9]. Even when investigating the effect of adjuvant chemotherapy and/or tamoxifen in node-negative breast cancer patients with a tumor size of $1 \mathrm{~cm}$ or less, a benefit for the addition of adjuvant therapy was noticed [10]. The recurrence-free survival for ER-positive patients was $86 \%$ after surgery alone, $93 \%$ when tamoxifen was added and $95 \%$ after the addition of tamoxifen and chemotherapy. Survival in the three groups was 90, 92, and 97\%, respectively, with a significant difference between the latter two groups. These authors concluded that use of chemotherapy and/or tamoxifen should be considered even for the treatment of women with ER-negative or ER-positive tumors of $1 \mathrm{~cm}$ or less and no axillary lymph node metastases.

As stated in an accompanying editorial, we need substantially more clinical and translational research to identify strong prognostic factors. It is only through such research that clinicians will be able to reliably distinguish those patients whose prognosis is sufficiently good that they can disregard the risks of treatment for those patients for whom the benefits far outweigh these risks, thus permitting us to apply beneficial but risky adjuvant therapy efficiently [11].

Due to the comparable small benefit of adding chemotherapy to certain subsets of node-negative breast cancer patients with a presumably excellent overall prognosis, one has to carefully weigh risk and benefit of this potentially toxic therapy.

\section{Clinical Prognostic Indicators in Node-Negative Breast Cancer}

Even though the premise 'first - select the target' [12] is the current paradigm for selecting adjuvant therapy in breast cancer, assessment of individual risk is of crucial importance when advising patients to undergo adjuvant therapy. Since single traditional prognostic factors alone are not sufficient to allow for proper risk assessment, combinations of several prognostic factors are commonly used for clinical decision making.

In Europe, the most commonly used risk classification is the St. Gallen risk category which is updated regularly after each bi-annual St. Gallen consensus meeting. This risk classification applies to node-negative as well as node-positive patients. However, node-positive patients do not meet the criteria for low risk.

Node-negative breast cancer patients are allocated according to the latest St. Gallen risk classification [3] as follows: lowrisk group if all of the following features $\left(\mathrm{T}_{1 \mathrm{a}-\mathrm{c}}, \mathrm{G} \mathrm{I}, \mathrm{ER}\right.$ and/or progesterone receptor (PR) expressed (positive), HER2 neither expressed nor amplified (negative), absence of peritumoral vascular invasion, age $\geq 35$ ) are present. If one of the above criteria is not met, patients are considered as intermediate risk (table 2).

In recent years several studies have validated the St. Gallen risk categories. Applying the 1998 risk classification to Japanese patients with node-negative breast cancer allocated only $3 \%$ to the minimal-/low-risk group [13] as compared to $10 \%$ of the Australian patients [14]. Even though these latter pa- 
Table 1. Choice of treatment modalities St. Gallen 2007

\begin{tabular}{llll}
\hline & $\begin{array}{l}\text { Highly endocrine } \\
\text { responsive }\end{array}$ & $\begin{array}{l}\text { Incompletely endocrine } \\
\text { responsive }\end{array}$ & $\begin{array}{l}\text { Endocrine non- } \\
\text { responsive }\end{array}$ \\
\hline HER2 negative & $\begin{array}{l}\text { ET (consider adding CT } \\
\text { according to risk) }\end{array}$ & $\begin{array}{l}\text { ET (consider adding CT } \\
\text { according to risk) }\end{array}$ & CT \\
HER2 positive & ET + trastuzumab + CT & ET + trastuzumab + CT & trastuzumab + CT
\end{tabular}

ET, Endocrine therapy; CT, chemotherapy
Table 2. Definition of risk categories for primary breast cancer St. Gallen 2007

\begin{tabular}{ll}
\hline Risk category & Definition \\
\hline Low risk & $\begin{array}{l}\text { node-negative AND all of the following features } \\
\mathrm{pT} \leq 2 \mathrm{~cm} \\
\text { grade } 1 \\
\text { age } \geq 35 \text { years } \\
\text { ER and/or PR expressed } \\
\text { absence of extensive peritumoral vascular invasion } \\
\text { HER2/neu gene neither overexpressed nor } \\
\text { amplified }\end{array}$ \\
\hline Intermediate risk & $\begin{array}{l}\text { node-negative AND } \text { at least one of the following } \\
\text { features: } \\
\text { pT }>2 \text { cm } \\
\text { grade } 2-3 \\
\text { presence of extensive peritumoral vascular invasion } \\
\text { ER and PR absent } \\
\text { HER2/neu gene overexpressed or amplified } \\
\text { age }<35 \text { years } \\
\text { node-positive (1-3 involved lymph nodes) AND } \\
\text { ER and/or PR expressed, AND } \\
\text { HER2/neu gene neither overexpressed nor amplified }\end{array}$ \\
$\begin{array}{l}\text { node-positive (1-3 involved lymph nodes) AND } \\
\text { ER and PR absent, OR } \\
\text { HER2/neu gene overexpressed or amplified } \\
\text { node positive (4 or more involved nodes) }\end{array}$ \\
\hline High risk
\end{tabular}

ER, Estrogen receptor; PR, progesterone receptor

tients had a 10 -year distant relapse-free survival of $100 \%$, the authors argued that an algorithm is useless if it spares only a small fraction of node-negative breast cancer patients from chemotherapy. A subsequent analysis of the 2001 St. Gallen classification by the same group of authors classified more patients as low risk with a 10-year distant disease-free survival (DSF) of 97\% [15]. Another validation of the 2001 risk classification in a cohort of Spanish patients showed a significant separation between high and low risk, but again classified only $14 \%$ as low risk [16]. Similarly, Otsuki and co-workers [17] investigated the 2003 modification of the St. Gallen risk classification and found a statistically significant separation of nodenegative cases between minimal and average risk considering DFS. However, they also noticed that only $17 \%$ of patients were classified as minimal risk and should thus have been spared chemotherapy. In Korean patients with node-negative breast cancer, only $4 \%$ were assigned to the minimal-risk group when applying the strict St. Gallen criteria of the 2003 consensus [18]. Indeed, despite the high sensitivity to detect high-risk patients, the St. Gallen risk classification is hampered by a comparably low specificity and by the fact that only a minority of node-negative breast cancer patients is allocated to the low-risk group for which chemotherapy can be safely omitted.

These 'traditional' prognostic factors are assessed in the webbased tool Adjuvant! online [19] which has over time gained widespread acceptance. This computer-based model uses age of the patient, a comorbidity assumption, tumor size, histological grade, ER status and number of lymph nodes involved for a calculation of relapse and survival at 10 years. Furthermore, it offers the possibility to estimate the potential benefit of a large array of chemotherapy regimens as well as endocrine therapies. This gives the oncologist the possibility to make joint decisions with their patients in each individual set of circumstances and is a step further towards personalized medicine.

In spite of the widespread acceptance of Adjuvant! it is surprising that only very few studies have as yet tried to validate this web-based prognostic tool. Olivotto and co-workers [20] stated that Adjuvant! performed reliably in a cohort of 4083 breast cancer patients from British Columbia when adjusting for certain risk factors. Conversely, Buyse and co-workers [21] failed to show a significant association with survival of nodenegative breast cancer patients when applying a predefined cut-off point to separate between low- and high-risk nodenegative breast cancer patients. On the contrary, a 70-gene signature showed a significant association with both distant DSF and overall survival (OS). For time to distant metastases, clinicopathologic risk using Adjuvant! software yielded an unadjusted hazard ratio $(\mathrm{HR})=1.68(95 \%$ confidence interval $(\mathrm{CI})$ $=0.92-3.07)$. For OS, Adjuvant! yielded an unadjusted HR = 1.67 (95\% CI $=0.93-2.98)$. Specificity for death within 10 years was improved using the gene signature (42\%) as compared to Adjuvant! (29\%) or to the St. Gallen risk category (10\%). We retrospectively compared Adjuvant! with the St. Gallen risk classification and a novel risk algorithm currently being prospectively evaluated in the clinicopathologic arm of the Node-Negative Breast Cancer-3 (NNBC-3) trial in 410 node-negative breast cancer patients without systemic adjuvant therapy [22]. The NNBC-3 algorithm defined high risk by any of the following criteria: (I) age $<35$ years, (II) G III, (III) 
HER2 positivity, (IV) vascular invasion, (V) PR negativity, (VI) G II tumors $>2 \mathrm{~cm}$. This algorithm enlarged the low-risk group to $37 \%$ as compared to Adjuvant! (17\%) and St. Gallen $(18 \%)$. In multivariate analysis, both Adjuvant! ( $p=0.027$; HR $3.81 ; 95 \%$ CI 1.16-12.47) and the NNBC-3 risk classification ( $\mathrm{p}=0.049$; HR $1.95 ; 95 \%$ CI $1.00-3.81$ ) significantly predicted OS, but only the NNBC-3 algorithm retained its prognostic significance in multivariate analysis for DFS $(p<0.0005)$. Specificity for distant metastasis or death was higher for the NNBC-3 algorithm (33\%) compared with Adjuvant! (19\%) or St. Gallen $(15 \%)$.

\section{Tumor Markers in Node-Negative Breast Cancer}

There is a plethora of potential prognostic factors or tumor markers in node-negative breast cancer. The American Society of Clinical Oncology (ASCO) published an update of their evidence-based clinical practice guidelines for the use of tumor markers in breast cancer in 2007 [23]. The following categories showed evidence of clinical utility and were recommended for use in practice: ER, PR, human epidermal growth factor receptor 2, urokinase-plasminogen activator (uPA), plasminogen activator inhibitor 1 (PAI-1), and certain multiparameter gene expression assays. However, not all applications for these markers were supported. The following categories demonstrated insufficient evidence to support routine use in clinical practice: DNA/ploidy by flow cytometry, immunohistochemistry-based markers of proliferation, p53, cathepsin D, cyclin E, proteomics, certain multiparameter assays, detection of bone marrow micrometastases, and circulating tumor cells. Especially for the estimation of prognosis in node-negative breast cancer only uPA/PAI-1 and Oncotype DX as a multiparameter gene expression assay were recommended. The precise clinical utility and appropriate application for other multiparameter assays, such as the MammaPrint assay, were classified as 'under investigation'.

This review will thus focus on UPA/PAI-1 and multiparameter gene expression analysis.

\section{uPA/PAl-1 in Node-Negative Breast Cancer}

UPA and PAI-1 are part of the plasminogen-activating system which has been shown experimentally to be associated with invasion, angiogenesis, and metastasis [24]. These factors are best measured with enzyme-linked immunosorbent assays (ELISA) in fresh-frozen tissue. Both uPA and PAI-1 have long been known to be associated with poor outcome in breast cancer [25-27]. A pooled analysis of UPA/PAI-1 data collected from 8377 breast cancer patients was performed by members of the Receptor and Biomarker Group of the European Organisation for Research and Treatment of Cancer. These results demonstrated the reproducibility of the assay among sev-
NNBC-3: Biological Risk Assessment

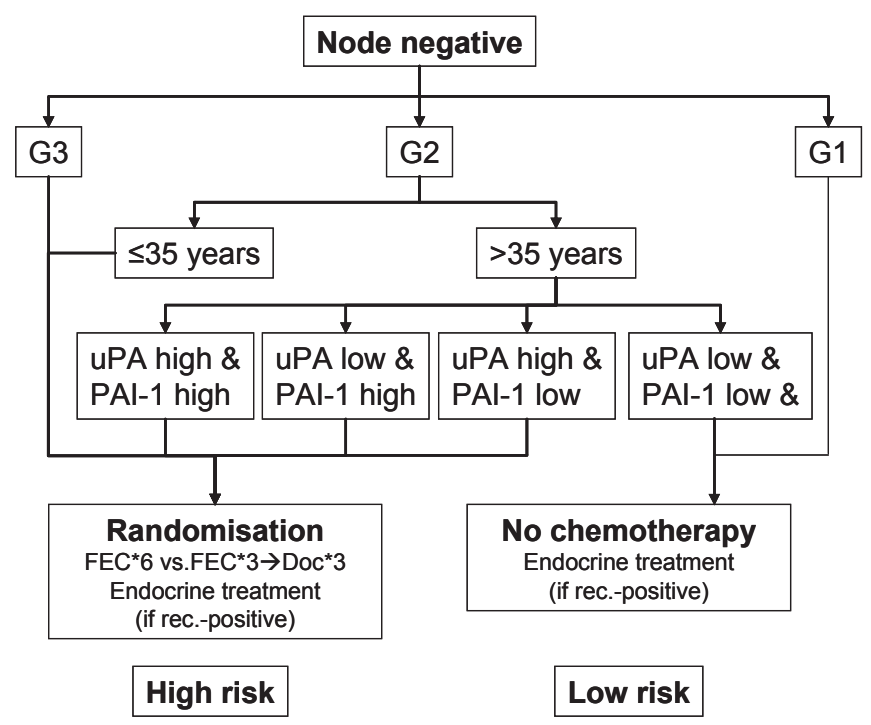

Fig. 1. Design of the NNBC-3 trial.

eral sites, and they confirmed the strong association of overexpression of UPA and PAI-1 with recurrence and survival during a median follow-up of 79 months. A subset analysis of node-negative, untreated patients also confirmed the potential utility of these markers for identifying a low-risk cohort in this group [28]. Furthermore, data from a prospective randomized trial showed that it is clinically relevant to use uPA/PAI-1 to stratify node-negative patients into a low-risk and a highrisk group [29]. The estimated 3-year recurrence rate for patients with low tumor levels of UPA and PAI- 1 was $6.7 \%$. This rate for patients with high tumor levels of uPA and/or PAI-1 was $14.7 \%(p=0.006)$. Furthermore, high-risk patients in the chemotherapy group showed a trend for benefit from chemotherapy, with a $43.8 \%$ lower estimated probability of disease recurrence at 3 years than high-risk patients in the observation group (intention-to-treat analysis: relative risk = $0.56 ; 95 \% \mathrm{CI}=0.25-1.28)$. These encouraging results led to the design of the ongoing NNBC-3 trial [30]. This trial uses uPA/PAI-1 for risk stratification of node-negative breast cancer patients and is expected to enroll 5700 patients. Patients with G I breast cancer and G II carcinomas with low uPA/PAI-1 levels are allocated to the low-risk group and will not receive chemotherapy. Patients with either G III carcinomas or G II tumors with high uPA/PAI-1 belong to the highrisk group (fig. 1). These patients will be randomized to receive either 6 cycles 5-fluorouracil/epirubicin/cyclophosphamid (FEC) d1 q3w or 3 cycles FEC followed by 3 cycles docetaxel $\mathrm{d} 1 \mathrm{q} 3 \mathrm{w}$. This trial will withhold adjuvant chemotherapy only from the low-risk node-negative breast cancer patients. Furthermore, it will answer the question whether highrisk node-negative breast cancer patients might benefit from a taxane-containing regimen. 


\section{Multiparameter Gene Expression Analysis in Node-Negative Breast Cancer}

The recent advent of gene expression profiling has allowed researchers to venture into the heterogeneous nature of breast cancer. Perou and co-workers [31] described breast cancer subtypes identified after two-dimensional hierarchical clustering, which they called luminal, basal like, normal like and ERBB2 like. These subtypes differed in their clinical outcome and response to chemotherapy [32-34]. However, the list of genes used to define these subtypes changed often and proliferation genes were largely neglected in the early publications. Furthermore, a simple, reproducible and comprehensible classification algorithm was difficult to deduce. In a more statistically driven case control design, also called supervised analysis, two different groups identified genes differentially expressed in tumors of node-negative and untreated patients who developed a metastasis within 5 years or remained disease free for at least 5 years $[35,36]$. The respective classification algorithms outperformed all other conventional prognostic factors and were confirmed in subsequent validation studies [37,38]. However, since both lists overlapped by only 3 genes, considerable uncertainty about the validity and general applicability of these findings arose in the medical community [39]. Meanwhile, it is becoming increasingly clear that most prognostic and predictive classification algorithms rely predominantly on the measurement of ER $\alpha$-regulated genes and genes involved in the cell cycle [40-43]. In particular, tumors scored as ER positive by immunohistochemistry can be subdivided into a good- and a badoutcome group by proliferation-associated genes [44].

Recently, the impact of the immune system on the prognosis of node-negative breast cancer patients became evident. In a meta-analysis, an immune response gene motive has been shown to distinguish between patients with good and bad outcome in ER-negative tumors [45]. In addition, it was found that high expression of lymphocyte-associated genes conferred a good prognosis in node-negative ERBB2-positive breast cancer [46]. In order to systematically evaluate the prognostic impact of the immune system, we performed gene expression profiling in a discovery cohort study of 200 untreated node-negative breast carcinomas [47]. After performing hierarchical cluster analysis, we identified co-regulated genes related to the biological process of proliferation, steroid hormone receptor expression, as well as B cell and T cell infiltration. We calculated metagenes as surrogate for all genes contained within a particular cluster and visualized the relative expression in relation to time to metastasis with principal component analysis. Distinct patterns led to the hypothesis of a prognostic role of the immune system in tumors with high expression of proliferation-associated genes. In multivariate Cox regression analysis, the proliferation metagene showed a significant association with metastasis-free survival of the whole discovery cohort (HR 2.20; 95\% CI 1.40-3.46). The B cell metagene showed additional independent prognostic in- formation in carcinomas with high proliferative activity (HR 0.66; 95\% CI 0.46-0.97). A prognostic influence of the B cell metagene was independently confirmed by multivariate analysis in a first validation cohort enriched for high-grade tumors ( $\mathrm{n}=286$; HR 0.78 ; 95\% CI 0.62-0.98), and a second validation cohort enriched for younger patients $(\mathrm{n}=302$; HR 0.83 ; $95 \%$ CI 0.7-0.97). Thus, we could demonstrate in three independent cohorts of untreated node-negative breast cancer patients that the humoral immune system plays a pivotal role for metastasis-free survival of carcinomas of the breast. However, albeit scientifically compelling, these novel findings should presently not be used to guide treatment decisions in node-negative breast cancer patients.

Currently, there are two ongoing clinical trials utilizing multiparameter gene expression analysis to stratify node-negative breast cancer patients.

\section{Trial Assigning Individualized Options for Treatment: TAILORx}

This trial [48] uses the Oncotype DX assay. This reverse transcriptase-polymerase chain reaction (RT-PCR) assay measures the expression of 21 genes in RNA extracted from formalin-fixed paraffin-embedded samples of tissue from primary breast cancer. This test was developed specifically for patients with ER-positive node-negative breast cancer patients treated with adjuvant tamoxifen. The 21 -gene validation study included 668 node-negative patients who participated in the NSABP B-14 trial for whom tumor blocks were available [49]. When evaluated as a categoric variable, the proportions of patients categorized as having a recurrence score (RS) defined as low $(<18)$, intermediate $(18-30)$, or high $(\geq 31)$ by the RT-PCR assay were 51, 22, and $27 \%$, respectively. The Kaplan-Meier estimates of the rates of distant recurrence at 10 years in the low-, intermediate-, and high-risk groups were $6.8,14.3$, and $30.5 \%$, respectively. The rate in the low-risk group was significantly lower than that in the high-risk group $(\mathrm{p}<0.001)$. In a multivariate Cox model, the RS provided significant predictive power that was independent of age and tumor size $(\mathrm{p}<0.001)$. The RS was also predictive of OS ( $\mathrm{p}<$ 0.001 ) and could be used as a continuous function to predict distant recurrence in individual patients. Subsequent studies in patients treated with tamoxifen with or without adjuvant chemotherapy in NSABP trial B-20 indicated that a high RS seemed to predict benefit from adjuvant chemotherapy [50]. The 21-gene assay was performed in a subset of 651 patients with tumor blocks available for analysis and showed a large chemotherapy benefit if the RS was high $(\mathrm{HR}=0.26$; $95 \% \mathrm{CI}$ $0.13-0.53)$. On the other hand, there was minimal, if any, benefit from chemotherapy if the RS was low (relative risk $=1.31$; 95\% CI 0.46-3.78). Patients with intermediate-RS tumors did not appear to have a large benefit, but the uncertainty in the estimate cannot exclude a clinically important benefit. 
TAILORx assigns treatment for patients who have a low RS (endocrine therapy alone) or a high RS (chemoendocrine therapy). Those who have an intermediate RS are randomly assigned to either chemoendocrine therapy (the standard treatment arm) or endocrine therapy alone (the experimental arm).

\section{Microarray in Node-Negative Disease May Avoid ChemoTherapy: MINDACT}

This trial uses the MammaPrint assay which was developed based on research initially conducted at The Netherlands Cancer Institute (Amsterdam) and collaborating institutions. Supervised classification generated a 70-gene expression profile that correlated with reduced distant DFS [35]. This signature was then validated in 295 consecutive stage I or II primary breast cancer patients younger than 53 years [37]. This second set included 61 patients with lymph node-negative disease used in the prior study that established the test. In this validation trial, the estimated HR for distant metastases by signature was $5.1(\mathrm{p}<0.001)$ and remained significant when adjusted for lymph node status. Moreover, it was independent of other prognostic factors like age, node status, tumor diameter, grade, vascular invasion or ER status by multivariable Cox regression analysis. In an effort to overcome possible inaccuracies like sample bias or model overfitting in these initial studies, the TRANSBIG research network performed a prospective validation trial in 302 lymph node-negative patients from five European cancer centers [21]. At a median follow-up of 13.6 years, this study found that the 70 -gene signature added independent prognostic information to conventional clinicopathologic risk assessment used in clinical practice, such as the Nottingham Prognostic Index, the St. Gallen criteria, and the Adjuvant! software. The MINDACT trial [51] is expected to enroll 6000 node-negative breast cancer patients who will have their risk assessed through both traditional clinicopathologic factors (using Adjuvant!) and the 70-gene profile (MammaPrint). If both methods classify the patient's risk of relapse as low, adjuvant chemotherapy is withheld; if both methods classify the patient's risk of relapse as high then chemotherapy will be proposed. In case these methods give discordant results, the patient will be randomly assigned to follow the clinicopathologic method or the genomic results.

\section{Conclusion}

At the present time, treatment decisions for node-negative breast cancer patients are based primarily on clinicopathologic risk assessment, e.g. the St. Gallen risk classification or Adjuvant! online. However, deciding which patient should be treated with chemotherapy is a continuing challenge for clinicians since these 'traditional' risk classifications have a high sensitivity but only a modest specificity and thus lead to potential overtreatment of a considerable number of node-negative breast cancer patients. From the plethora of novel prognostic factors or tumor markers only uPA/PAI-1 and Oncotype DX have received an evidence-based recommendation for use in clinical practice from ASCO. The MammaPrint assay was classified as 'under investigation'. Study participation of node-negative breast cancer patients in either the NNBC-3 trial, the MINDACT trial or TAILORx is strongly encouraged. These studies will hopefully allow us to quantify the risk of progression in the individual patient and tailor treatment accordingly. This should lead to a more personalized treatment recommendation and thus should help to overcome our less than satisfactory 'one size fits all' approach to early breast cancer treatment. Close interdisciplinary collaboration between clinicians and scientists will be essential to achieve this goal.

\section{References}

${ }_{1}$ Berry DA, Cronin KA, Plevritis SK, Fryback DG, Clarke L, Zelen M, Mandelblatt JS, Yakovlev AY, Habbema JD, Feuer EJ: Effect of screening and adjuvant systemic therapy on mortality from breast cancer. N Engl J Med 2005;353:1784-1792.

2 Early Breast Cancer Trialists' Collaborative Group (EBCTCG): Effects of chemotherapy and hormonal therapy for early breast cancer on recurrence and 15-year survival: an overview of the randomised trials. Lancet 2005;365:1687-1717.

$\checkmark 3$ Goldhirsch A, Wood WC, Gelber RD, Coates AS, Thürlimann B, Senn HJ: Progress and promise: highlights of the international expert consensus on the primary therapy of early breast cancer 2007 . Ann Oncol 2007;18:1133-1144.

4 Shapiro CL, Recht A: Side effects of adjuvant treatment of breast cancer. N Engl J Med 2001;344 1997-2008.

5 Ganz PA, Desmond KA, Leedham B, Rowland JH, Meyerowitz BE, Belin TR: Quality of life in longterm, disease-free survivors of breast cancer: a follow-up study. J Natl Cancer Inst 2002;94:39-49.
6 Chia SK, Speers CH, Bryce CJ, Hayes MM, Olivotto IA: Ten-year outcomes in a population-based cohort of node-negative, lymphatic, and vascular invasion-negative early breast cancers without adjuvant systemic therapies. J Clin Oncol 2004;22: 1630-1637.

7 Fisher ER, Costantino J, Fisher B, Redmond C: Pathologic findings from the National Surgical Adjuvant Breast Project (Protocol 4). Cancer 1993;71: 2141-2150.

8 Jatoli I, Hilsenbeck SG, Clark GM, Osborne CK: Significance of axillary lymph node metastasis in primary breast cancer. J Clin Oncol 1999;17: 2334-2340.

9 Fisher B, Jeong JH, Bryant J, Anderson S, Dignam J, Fisher ER: Treatment of lymph-node-negative, oestrogen-receptor-positive breast cancer: longterm findings from National Surgical Adjuvant Breast and Bowel Project randomised clinical trials. Lancet 2004;364:858-868.
10 Fisher B, Dignam J, Tan-Chiu E, Anderson S, Fisher ER, Wittliff JL, Wolmark N: Prognosis and treatment of patients with breast tumors of one centimetre or less and negative axillary lymph nodes. J Natl Cancer Inst 2001;93:112-120.

11 Lippman ME, Hayes DF: Adjuvant therapy for all patients with breast cancer. J Natl Cancer Inst 2001;93:80-92.

12 Goldhirsch A, Coates AS, Gelber RD, Glick JH, Thürlimann B, Senn HJ: First - select the target: better choice of adjuvant treatments for breast cancer patients. Ann Oncol 2006;17:1772-1776.

13 Iwamoto E, Fukutomi T, Akashi-Tanaka S: Validation and problems of St. Gallen recommendations of adjuvant therapy for node-negative invasive breast cancer in Japanese patients. Jpn J Clin Oncol 2001;31:259-262.

14 Boyages J, Chua B, Taylor R, Bilous M, Salisbury E, Wilcken N, Ung O: Use of the St Gallen classification for patients with node-negative breast cancer may lead to overuse of adjuvant chemotherapy. Br J Surg 2002;89:789-796. 
15 Boyages J, Taylor R, Chua B, Ung O, Bilous M, Salisbury E, Wilcken N: A risk index for early node-negative breast cancer. Br J Surg 2006;93: 564-571.

16 Colomer R, Vinas G, Beltran M, Izquierdo A, Lluch A, Llombart-Cussac A, Alba E, Munárriz B, Martín M: Validation of the 2001 St. Gallen risk categories for node-negative breast cancer using a database from the Spanish Breast Cancer Research Group (GEICAM). J Clin Oncol 2004;22:691.

17 Otsuki Y, Shimizu S-I, Suwa K, Yoshida M, Kanzaki M, Kobayashi H: Which is the better pathological prognostic factor, the Nottingham histological grade or the Japanese nuclear grade? A large scale study with long-term follow-up. Jpn J Clin Oncol 2007;37:266-274.

18 Sun J-M, Han W, Im S-A, Kim TY, Park IA, Noh DY, Heo DS, Bang YJ, Choe KJ, Kim NK: A combination of HER-2 status and the St. Gallen classification provides useful information on prognosis in lymph-node negative breast carcinoma. Cancer 2004;101:2516-2522.

19 Ravdin PM, Siminoff LA, Davis GJ, Mercer MB, Hewlett J, Gerson N, Parker HL: Computer program to assist in making decisions about adjuvant therapy for women with early breast cancer. J Clin Oncol 2001;19:980-991.

20 Olivotto IA, Bajdik CD, Ravdin PM, Speers CH, Coldman AJ, Norris BD, Davis GJ, Chia SK, Gelmon KA: Population-based validation of the prognostic model ADJUVANT! for early breast cancer. J Clin Oncol 2005;23:2716-2725.

-21 Buyse M, Loi S, van't Veer L, Viale G, Delorenzi M, Glas AM, d'Assignies MS, Bergh J, Lidereau R, Ellis P, Harris A, Bogaerts J, Therasse P, Floore A, Amakrane M, Piette F, Rutgers E, Sotiriou C, Cardoso F, Piccart MJ: Validation and clinical utility of a 70-gene prognostic signature for women with node-negative breast cancer. J Natl Cancer Inst 2006;98:1183-1192.

22 Schmidt M, Victor A, Bratzel D, Boehm D, Cotarelo C, Lebrecht A, Siggelkow W, Hengstler JG, Elsässer A, Gehrmann M, Lehr HA, Koelbl H, von Minckwitz G, Harbeck N, Thomssen C: Long-term outcome prediction by clinico-pathological risk classification algorithms in node-negative breas cancer - comparison between Adjuvant!, St. Gallen, and a novel risk algorithm used in the prospective randomized Node-Negative-BreastCancer-3 (NNBC-3) trial. Ann Oncol, in press.

23 Harris L, Fritsche H, Mennel R, Norton L, Ravdin P, Taube S, Somerfield MR, Hayes DF, Bast RC Jr: American Society of Clinical Oncology 2007 update of recommendations for the use of tumor markers in breast cancer. J Clin Oncol 2007;25: 5287-5312.

24 Stephens RW, Brünner N, Jänicke F, Schmitt M: The urokinase plasminogen activator system as a target for prognostic studies in breast cancer. Breast Cancer Res Treat 1998;52:99-111.

25 Jänicke F, Schmitt M, Pache L, Ulm K, Harbeck N, Höfler H, Graeff H: Urokinase (uPA) and its inhibitor PAI-1 are strong and independent prognostic factors in node-negative breast cancer. Breast Cancer Res Treat 1993;24:195-208.

26 Bouchet C, Spyratos F, Martin PM, Hacène K, Gentile A, Oglobine J: Prognostic value of urokinasetype plasminogen activator (uPA) and plasminogen activator inhibitors PAI- 1 and PAI- 2 in breast carcinomas. Br J Cancer 1994;69:398-405.

27 Harbeck N, Dettmar P, Thomssen C, Berger U, Ulm K, Kates R, Höfler H, Jänicke F, Graeff H, Schmitt M: Risk-group discrimination in node-negative breast cancer using invasion and proliferation markers: 6-year median follow-up. Br J Cancer 1999;80:419-426.
28 Look MP, van Putten WL, Duffy MJ, Harbeck N, Christensen IJ, Thomssen C, Kates R, Spyratos F, Fernö M, Eppenberger-Castori S, Sweep CG, Ulm K, Peyrat JP, Martin PM, Magdelenat H, Brünner N, Duggan C, Lisboa BW, Bendahl PO, Quillien V, Daver A, Ricolleau G, Meijer-van Gelder ME, Manders P, Fiets WE, Blankenstein MA, Broët P, Romain S, Daxenbichler G, Windbichler G, Cufer T, Borstnar S, Kueng W, Beex LV, Klijn JG, O'Higgins N, Eppenberger U, Jänicke F, Schmitt M, Foekens JA: Pooled analysis of prognostic impact of urokinase-type plasminogen activator and its inhibitor PAI-1 in 8377 breast cancer patients. J Natl Cancer Inst 2002;94:116-128.

29 Jänicke F, Prechtl A, Thomssen C, Harbeck N, Meisner C, Untch M, Sweep CG, Selbmann HK, Graeff H, Schmitt M: Randomized adjuvant chemotherapy trial in high-risk, lymph node-negative breast cancer patients identified by urokinasetype plasminogen activator and plasminogen activator inhibitor type 1. J Natl Cancer Inst 2001; 93:913-920.

30 Annecke K, Schmitt M, Euler U, Zerm M, Paepke D, Paepke S, von Minckwitz G, Thomssen C, Harbeck N: uPA and PAI-1 in breast cancer: Review of their clinical utility and current validation in the prospective NNBC-3 trial. Adv Clin Chem 2007; 45:31-45.

31 Perou CM, Sorlie T, Eisen MB, van de Rijn M, Jeffrey SS, Rees CA, Pollack JR, Ross DT, Johnsen H, Akslen LA, Fluge O, Pergamenschikov A, Williams C, Zhu SX, Lønning PE, Børresen-Dale AL, Brown PO, Botstein D: Molecular portraits of human breast tumors. Nature 2000;406:747-752.

32 Sorlie T, Perou CM, Tibshirani, R, Aas T, Geisler S, Johnsen H, Hastie T, Eisen MB, van de Rijn M, Jeffrey SS, Thorsen T, Quist H, Matese JC, Brown PO, Botstein D, Lonning PE, Borresen-Dale AL: Gene expression patterns of breast carcinomas distinguish tumor subclasses with clinical implications. PNAS 2001;98:10869-10874.

33 Sorlie T, Tibshirani R, Parker J, Hastie T, Marron JS, Nobel A, Deng S, Johnsen H, Pesich R, Geisler $\mathrm{S}$, Demeter J, Perou CM, Lonning PE, Brown PO, Borresen-Dale AL, Botstein D: Repeated observation of breast tumor subtypes in independent gen expression data sets. PNAS 2003;100:8418-8423.

34 Rouzier R, Perou CM, Symmans WF, Ibrahim N, Cristofanilli M, Anderson K, Hess KR, Stec J, Ayers M, Wagner P, Morandi P, Fan C, Rabiul I, Ross JS, Hortobagyi GN, Pusztai L: Breast cancer molecular subtypes respond differently to preoperative chemotherapy. Clin Cancer Res 2005;11:5678-5685.

35 Van't Veer LJ, Dai H, van de Vijver MJ, He YD, Hart AA, Mao M, Peterse HL, van der Kooy K, Marton MJ, Witteveen AT, Schreiber GJ, Kerkhoven RM, Roberts C, Linsley PS, Bernards R, Friend SH: Gene expression profiling predicts clinical outcome of breast cancer. Nature 2002;415: 530-536.

36 Wang Y, Klijn JG, Zhang Y, Sieuwerts AM, Look MP, Yang F, Talantov D, Timmermans M, Meijervan Gelder ME, Yu J, Jatkoe T, Berns EM, Atkins D, Foekens JA: Gene-expression profiles to predict distant metastasis of lymph-node-negative primary breast cancer. Lancet 2005;365:671-679.

37 Van de Vijver MJ, He YD, van't Veer LJ, Dai H, Hart AA, Voskuil DW, Schreiber GJ, Peterse JL, Roberts C, Marton MJ, Parrish M, Atsma D, Witteveen A, Glas A, Delahaye L, van der Velde T, Bartelink H, Rodenhuis S, Rutgers ET, Friend SH, Bernards R: A gene-expression signature as a predictor of survival in breast cancer. N Engl J Med 2002;347:1999-2009.

38 Foekens JA, Atkins D, Zhang Y, Sweep FC, Harbeck N, Paradiso A, Cufer T, Sieuwerts AM, Talantov D, Span PN, Tjan-Heijnen VC, Zito AF, Specht
K, Hoefler H, Golouh R, Schittulli F, Schmitt M, Beex LV, Klijn JG, Wang Y: Multicenter validation of a gene expression-based prognostic signature in lymph node-negative primary breast cancer. J Clin Oncol 2006;24:1665-1671.

39 Brenton JD, Carey LA, Ahmed AA, Caldas C: Molecular classification and molecular forecasting of breast cancer: ready for clinical application? J Clin Oncol 2005;23:7350-7360.

40 Sotiriou C, Wirapati P, Loi S, Harris A, Fox S, Smeds J, Nordgren H, Farmer P, Praz V, HaibeKains B, Desmedt C, Larsimont D, Cardoso F, Peterse H, Nuyten D, Buyse M, Van de Vijver MJ, Bergh J, Piccart M, Delorenzi M: Gene expression profiling in breast cancer: Understanding the molecular basis of histologic grade to improve prognosis. J Natl Cancer Inst 2006;98:262-272.

41 Oh DS, Troester MA, Usary J, Hu Z, He X, Fan C, Wu J, Carey LA, Perou CM: Estrogen-regulated genes predict survival in hormone receptor-positive breast cancers. J Clin Oncol 2006;24:1656-1664.

42 Fan C, Oh DS, Wessels L, Weigelt B, Nuyten DS, Nobel AB, van't Veer LJ, Perou CM: Concordance among gene-expression-based predictors for breast cancer. N Engl J Med 2006;355:560-569.

43 Desmedt C, Piette F, Loi S, Wang Y, Lallemand F, Haibe-Kains B, Viale G, Delorenzi M, Zhang Y, d'Assignies MS, Bergh J, Lidereau R, Ellis P, Harris AL, Klijn JG, Foekens JA, Cardoso F, Piccart MJ, Buyse M, Sotiriou C: Strong time dependence of the 76-gene prognostic signature for node-negative breast cancer patients in the TRANSBIG multicenter independent validation series. Clin Can Res 2007;13:3207-3214.

44 Loi S, Haibe-Kains B, Desmedt C, Lallemand F, Tutt AM, Gillet C, Ellis P, Harris A, Bergh J, Foekens JA, Klijn JG, Larsimont D, Buyse M, Bontempi G, Delorenzi M, Piccart MJ, Sotiriou C: Definition of clinically distinct molecular subtypes in estrogen receptor-positive breast carcinomas through genomic grade. J Clin Oncol 2007;25:1239-1246.

45 Teschendorff A, Miremadi A, Pinder SE, Ellis IO, Caldas C: An immune response gene expression module identifies a good prognosis subtype in estrogen receptor negative breast cancer. Genome Biol 2007;8:R157.

46 Alexe G, Dalgin GS, Scanfeld D, Tamayo P, Mesirov JP, DeLisi C, Harris L, Barnard N, Martel M, Levine AJ, Ganesan S, Bhanot G: High expression of lymphocyte-associated genes in node-negative HER2+ breast cancer correlates with lower recurrence rates. Cancer Res 2007;67:10669-10676.

47 Schmidt M, Böhm D, von Törne C, Steiner E, Puhl A, Pilch H, Lehr HA, Hengstler JG, Kölbl H, Gehrmann M: The humoral immune system has a key prognostic impact in node-negative breast cancer. Cancer Res 2008;68:5405-5413.

48 Sparano JA, Paik S: Development of the 21-gene assay and its application in clinical practice and clinical trials. J Clin Oncol 2008;26:721-728.

49 Paik S, Shak S, Tang G, Kim C, Baker J, Cronin M, Baehner FL, Walker MG, Watson D, Park T, Hiller W, Fisher ER, Wickerham DL, Bryant J, Wolmark $\mathrm{N}$ : A multigene assay to predict recurrence of tamoxifen-treated, node-negative breast cancer. N Engl J Med 2004;351:2817-2826.

50 Paik S, Tang G, Shak S, Kim C, Baker J, Kim W, Cronin M, Baehner FL, Watson D, Bryant J, Costantino JP, Geyer CE Jr, Wickerham DL, Wolmark N: Gene expression and benefit of chemotherapy in women with node-negative, estrogen receptor-positive breast cancer. J Clin Oncol 2006;24: 3726-3734

51 Cardoso F, Van't Veer L, Rutgers E, Loi S, Mook S, Piccart-Gebhart MJ: Clinical application of the 70-gene profile: the MINDACT trial. J Clin Oncol 2008;26:729-735. 